\title{
Saving the Great Barrier Reef from Disaster, Media Then and Now
}

\author{
Kerrie Foxwell-Norton \\ Griffith Centre for Cultural Research, Griffith University, Australia
}

\section{Libby Lester}

School of Social Sciences, University of Tasmania, Australia

Keywords: Great Barrier Reef, Media, Environmental Communication, World Heritage, Environmental Protest, Fight for the Reef

\begin{abstract}
The Great Barrier Reef is the most recognizable of the Australian properties on UNESCO's World Heritage List. At the time of its inscription in 1981, the International Union for the Conservation of Nature noted that '... if only one coral reef site in the world were to be chosen for the World Heritage List, the Great Barrier Reef is the site to be chosen'. The listing followed the 'Save the Reef' campaign, which ran through the 1960s and 1970s and highlighted threats from rapid industrialization and a nation riding a resources boom. Nevertheless, in recent years, the Reef has teetered on being named a 'World Heritage Site in Danger', with similar economic conditions driving its deterioration. This paper juxtaposes recent media activism to protect the Reef against the earlier campaign in order to compare and better understand how these campaigns engaged publics and policy makers by representing and communicating threats, and concludes by considering their capacity to influence long-term conservation policy.
\end{abstract}




\section{Introduction}

The Great Barrier Reef is an internationally recognised wonder of the natural world - a global nature superstar. Its scientific credentials are exceptional with a list of marine creatures that includes 600 types of soft and hard corals, more than 100 species of jellyfish, 3000 varieties of molluscs, 500 species of worms, 1625 types of fish, 133 varieties of sharks and rays, and more than 30 species of whales and dolphins. The Great Barrier Reef Marine Park covers 344,400 km2 and contains the world's largest coral reef ecosystem with 3000 coral reefs, 600 continental islands, 300 coral cays and 150 inshore mangrove islands. The Reef is part of Australia's national identity, with Australians defining themselves as coastal dwellers 'living on the edge' (Drew, 1994), and it is a site of historical and contemporary Indigenous cultural heritage, retaining significance to Australia's First Nations people, especially those whose traditional lands border the Reef. It is the location of a brutal colonial history, invasion and frontier encounters, also part of the Australian identity (McCalman, 2013). From an economic perspective, the Reef brought $\$ 5.7$ billion to the Australian economy in 2012 with employment of almost 69,000 full-time equivalent workers (Deloitte Access Economics, 2013). Stretching for $2500 \mathrm{~km}$ along the Queensland coast, it supports numerous regional towns, communities and businesses, particularly reliant on tourism and fishing and thus the continued status of the Reef as a holiday destination.

In this paper, we examine two distinct periods of conflict in the history of this nature superstar: the 'Save the Reef' campaign of the 1960s and 1970s and the more recent 'Fight for the Reef' campaign. Media communications have played an important role in both, and it is within the context of major change to media practices, logics and technologies - alongside dynamic social and political settings - that we locate and analyse specific features of these campaigns. In doing so, we hope to contribute to important debates within media and communications - that is, the bounds and opportunities for the public to participate in debates on shared environmental futures, and the potential impact of such campaigns and debates on the formation of policy.

The campaigns have both focused on preventing the destruction of the Reef. In 1967, Australian artist and environmental campaigner John Büsst read a 
public notice in a small community newspaper that a local farmer had applied to mine limestone on Ellison Reef, offshore and about midway between the small Queensland communities of Innisfail and Mission Beach. The limestone from the Ellison Reef coral was to be used by local sugar cane growers as fertiliser, and required little transportation or further treatment. After seven years of protest and political maneuvering (see Hutton and Connors, 1999), the Great Barrier Reef became a marine park in 1974 with World Heritage listing following in 1981. The story of the proposal to mine limestone on Ellison Reef and its implications for Reef protection has been told in various forums, with most focused on surrounding politics and protest (Clare, 1971; Wright ,1977; McCalman, 2013; Bowen and Bowen, 2002; Evans, 2007; and Hutton and Connors, 1999). This paper offers another dimension by considering the strategic and media communications of the campaign.

'Fight for the Reef' launched in 2012 as a partnership between the Australian Marine Conservation Society and WWF-Australia in response to major development proposals. These proposals had also prompted a World Heritage monitoring mission as they included a massive expansion of coal mining and associated activities in Queensland, with nine mines proposed in the Galilee Basin deposit 400kms inland from the Reef. The Carmichael mine, owned by Indian-based company, the Adani Group, was to produce 60 million tonnes of coal a year (Adani, 2014). MacMines Austasia, now solely owned by the Meijin energy group, one of China's largest producers of coal, was approved to produce 70 million tonnes of coal a year with an expected mine life of 40 years. Coal from both mines, along with others awaiting approval, would be transported to expanded shipping facilities at Abbot Point, on the central Queensland coast, where dredging was proposed to allow ships transporting the coal to make their way through the reef. While legal action and a change of state government has left the status of the proposal unclear, governments at both state and federal levels continue to reassure investors of their commitment to the Queensland coal industry.

To begin outlining the political and social contexts and a conceptual framework for our study, it is useful to emphasise that although media landscapes of today seem barely recognisable to those of 1967, media have in 
fact played a long and continuing role in the communications of environmental risks and concerns. Media centrality in the communication of a range of environmental issues, events and places and the negotiation of shared environmental futures is well recognised (Hansen, 2010; Cox, 2012; Lester, 2010). Our case reinforces that centrality. From the Reef's 'discovery' by white explorers and early Australian colonial settlers, media have played a critical role in communicating knowledge about the Reef to the world. Today, despite the relatively high visitor numbers to the region, few people still have direct experience of the Reef, in particular the outer Reef, from where our visual representations largely emanate. The fact that John Büsst was alerted to the threat to mine the Great Barrier Reef by a notice in his local newspaper is also salient.

However, at the time Büsst was reading of the plans to mine Ellison Reef, various crucial transformations were underway. In 1960s regional Australia, email and the Internet were decades away, and translocal communication was mostly by an often inefficient mail system or expensive timed telephone calls. Television was barely a decade old in metropolitan areas and still not available in large parts of regional Australia, and colour television would not be introduced to Australian homes until the mid 1970s. Meanwhile, the images of the Earth from space from the Apollo 8 mission in 1968 were greeted as remarkable; a 'communications moment' which some have identified as signaling the birth of the modern environmental movement (Cosgrove, 1984; Lester, 2010). The mission also involved a radio broadcast and in the words of one of the Apollo astronauts, Frank Borman: 'We were told that on Christmas Eve we would have the largest audience that had ever listened to a human voice...'. (NASA, 2014). In this sense, a simultaneous moment of global environmental communication and consciousness was occurring, although such a moment was only possible because of a collective awareness and movement towards care for the environment and associated politics. This included, for example, Rachel Carson's A Silent Spring (1962), which had reached Australian shores as a campaign tool for activists wanting to highlight the threat of industrial production and processes, the appointment of dedicated environment reporters by Australian newspapers, and the loss of the picturesque Lake Pedder 
in Tasmania's remote south west after a protracted nation-wide battle against the hydro-electric development (Lester, 2010, 2014).

The first environmental policies designed to address the consequences of large-scale industrial production and development were also beginning to appear. In the United States, environmental policies to police industrial production, particularly nefarious impacts on water and air quality, emerged. On an international scale, in 1968 Sweden suggested to the UN Economic and Social Council a conference to focus on human interactions and the environment, eventually leading to the UN Stockholm Conference in 1972 and its focus on environment and development. International policy and programs also gained significant momentum with 'World Heritage' established at the 1972 Paris UNESCO Conference, thus delivering a mechanism for the protection of the global natural and cultural places of outstanding value. Australia was one of the first nations to ratify the World Heritage Convention, doing so in 1974 before the convention came into force in 1975 (Australian Government, n.d.).

In 1981, a meeting of the World Heritage Committee was held in Sydney. Chaired by Australia's then Prime Minister Malcolm Fraser, the meeting inscribed Australia's first World Heritage properties: Kakadu National Park, the Willandra Lakes Region and the Great Barrier Reef. The United Nations Convention on the Law of Sea, while not passed until 1982, also gained momentum during the 1960s with the enactment of four treaties that began to further define state sovereignty and territorial waters. Environmental policy and law became the formal mechanisms at local, national and international levels to administer and safeguard environments. Alongside this growing global environmental consciousness, communications facilitated the growth of global capital. While this matrix of law and policy to protect environments in the context of global communications and capital was emergent during the earlier 'Save the Reef 'campaign, it was fully instituted fifty years later during the 'Fight for the Reef' campaign.

Increased awareness of risks posed by industrialisation and pressure to mitigate environmental harms have been identified as defining features of the later period of our study (Beck, 2009). Escalating evidence and accompanying concern about the threat of industrial practices on environments - accessed via 
new forms and flows of information and images - have transformed the ways in which the world (or at least those with access to communication technologies) understand environments. Beck's (2009) concept of 'relations of definitions' depicts the complexity of the terrain. Here is a '...matrix of interests and ideas and the different rationality claims (both scientific and social) that publicly define, contend and challenge within the [environmental] risk field including the media' (Cottle, 2006). Recent theorising of media and environmental conflict in a networked society has argued that media are both 'performative' and 'constitutive', with environmental conflicts a key site for the recognition of these processes (Lester and Cottle, 2009; Hutchins and Lester, 2015). As such communications and the media have become inextricably infused in and are indispensible to protests, publics and media participation' (Lester and Cottle, 2015: 108).

Simon Cottle (2014) has identified six characteristics of media and communications, which he argues are 'historically unparalleled' and point to the 'extensity and intensity' of the contemporary communications environment and in particular, its potential to mediatize disasters - disasters which at the current historical juncture are indicative of global crises no longer contained within nation states. These are: Scale: information can be transmitted simultaneously on a global scale; Speed: time has collapsed undermining traditional methods of information management; Saturation: universalising means of communication (for example, mobile phones) with accompanying expectations of access and preparedness to use; Social Relations Enfranchisement: or universalising technologies that communicatively expand and enfranchise social relations; Surveillance: keeping disasters 'out of sight' or off the political radar is unlikely due especially to satellite monitoring of governments and civil society actors and finally; Visibility: we can not only read and hear but can see disaster and global crises.

Campaigns surrounding the Great Barrier Reef are illustrative of these observations. The Reef is - as the World Heritage Committee, Great Barrier Reef Marine Authority and environmental campaigns agree - a pinnacle example of an environment visibly on the edge of disaster as a consequence of the factors not contained within state borders, namely climate change but also and relatedly, 
international markets and industry pressuring for continuing developments that impact Reef health. Yet, we know little about our capacity to raise public consciousness and therefore incite reparatory actions within these conditions. A sobering observation is that the potential for change and challenge remains principally open to those in established positions of power (Lester and Hutchins, 2009). Questions must therefore continue to be framed that interrogate apparent and enduring power structures and discourses typical of industrial society, alongside the potential of new media ecologies to foster and develop positive environmental futures and sustained outcomes for the Reef.

In order to progress the framing of these questions, this paper revisits accounts of the 'Save The Reef' campaign (especially Wright, 1977) alongside a contemporary investigation of the 'Fight for the Reef' campaign, focusing specifically on the role of media and communications in raising public awareness of the Reef in danger. Comparing protest actions half a century apart provides insight into the changing relationship between environmental protest and communication media and its potential to incite public participation in Reef decision-making and policy direction ${ }^{\mathrm{i}}$. In the next sections, we detail key campaign moments and contexts to examine the role and efficacy of media and communications in challenging industrial threats to the Reef.

\section{Save the Reef}

While the phrase 'Save the Reef' was initially adopted by a group that formed the 'Save the Reef Committee' - which, according to Judith Wright (1977: 84), helped the work of existing conservationist groups such as the Queensland Wildlife Preservation Society - we use it here to describe the overall network of individuals, organisations and events that emerged in the late 1960s to campaign on behalf of the Reef. The phrase can also be seen as emblematic of the overall campaign period as 'Save the Reef' bumper stickers became widespread during this time. With its genesis in local community action, 'Save the Reef' would eventually become a national concern with a number of newly established environmental organisations and a collection of individuals mobilizing to protect the Reef from various threats. Alongside mining, these included destructive infestations of Crown of Thorns starfish, whose presence on the Reef were 
believed to be a consequence of the commercial and tourist removal of its chief predator, the Triton shell; and oil spills, with fears of disaster driven by the US's Santa Barbara Oil Spill of January 1969. Two organizations in particular figure prominently in this period: the Queensland Wildlife Preservation Society and the Queensland Littoral Society.

The Queensland Wildlife Preservation Society was founded in 1962 by distinguished Australian poet Judith Wright alongside publisher Brian Clouston and others as a community-based, non-profit organisation. The formation of a branch in the town of Innisfail by John Büsst followed in 1966. Communication and media were initial priorities, with Brian Clouston - as owner of Jacaranda Press - offering to publish a magazine that would collect ideas of society founders and members into single volume for distribution to a larger audience. Wildlife Magazine, still in publication, became an initial focus of the society. The Preservation Society's access to good writers was a critical advantage in mounting the campaign to save the Reef. In contrast, the Queensland Littoral Society, which is now known at the Australian Marine Conservation Society and a formal partner in the 'Fight for the Reef' Campaign, was formed in 1965 in Brisbane by scientists and students from the University of Queensland and Australia's premier scientific research body, CSIRO. Prominent in its ranks was Dr Len Webb, at the time one of the few ecologists in Australia. The discipline was still much maligned by the more established sciences in the early 1960s, but its rise and recognition throughout the decade with its basic premise of interconnectedness of ecosystems was critical to the campaign against mining of Ellison Reef. Some assessments of the Reef had argued that 'dead coral' could be mined but Webb and others were able to challenge these ideas from the legitimate space of 'scientific knowledge' (see Bowen and Bowen, 2002; McCalman, 2013; Hutton and Connors, 1999; Wright, 1977). Eventually, the unlikely trio of poet Judith Wright, forester/ecologist Len Webb and artist John Büsst came together to lead the campaign (McCalman, 2013).

The communication of the Reef in crisis in the 1960s occurred across multiple platforms. The 'Save the Reef' campaign was built upon mainstream media platforms - radio, print and television - supported by alternative media in the form of Wildlife Magazine, newsletters and community media such as local 
radio and newspapers. Interpersonal and organizational communications between the chief protagonists were also important, although the speed was somewhat reduced by the postal services and telephony available at the time. Nevertheless, Büsst dispatched 4000 letters across the globe during his campaign (Queensland Heritage Register, nd).

Australian mainstream media were critical to the success of 'Save the Reef' with news coverage consistently sought and triumphantly celebrated. Judith Wright well understood the power of media, as this excerpt from her 1977 foreword to The Coral Battleground illustrates:

...I wish to acknowledge the role of the press, both in reporting and in producing special articles and surveys, throughout the whole campaign from its inception in the Ellison Reef case. I make particular acknowledgement to The Australian, whose full and faithful coverage was a most important fact in the amount of public interest and information on the whole question. (Wright, 1977: xxiii)

In an early analysis of the Save the Reef campaign, Des Connell, then a chemistry PhD student and President of the Queensland Littoral Society, summarized the lessons for conservationists of the campaign and media roles:

It is quite clear that sound and detailed knowledge of the problems and surrounding circumstances was a first essential requirement. This information then needs to be disseminated to the community by means of publications, public meetings, addresses to private organizations, and all the forms of mass media that can be utilized. Even after all of these actions have been taken, results cannot be achieved overnight, and both patience and perseverance are required. (Connell, 1971: 254)

While noting the impact of the press and television overall, Wright also acknowledged the impact of individual journalists. Barry Wain, at the then newly 
established Brisbane office of the Rupert Murdoch flagship The Australian, was singled out (Wright, 1977). Other journalists also figure in contemporary accounts, in particular Patricia Clare who wrote the book, The Struggle for the Great Barrier Reef (1971), based on a series of interviews with vocal Reef stakeholders including scientist, farmers, activists and local Indigenous people.

Media coverage of the 1969 Santa Barbara oil blowout in the United States also aided the campaign by raising 'what if' anxieties in the Australian community. Concerns were not alleviated by reporting of comments from the then Queensland State Mines Minister, R. E. (Ron) Camm, who stated that similar damage to the reef could not occur as ocean currents would direct the oil away from the Reef. With 80 per cent of the Reef leased for oil drilling permits, alarm was further amplified by Camm's comments that research could be conducted by pouring oil onto the Reef to determine its effect. In September 1969 The Courier Mail published a map of the reef region leased for oil drilling (in Wright, 1977: 71), naming the companies with leases - details which had been until then shrouded in secrecy. Federal politicians who had been at odds with the conservative Queensland state government supported a parliamentary enquiry, which would eventually lead to the establishment of the Great Barrier Reef Marine Park Act; defining and establishing Commonwealth rather than state jurisdiction over management of the Reef. The publication of this material also led to the revelation that the Queensland Premier, Joh Bjelke-Petersen, had pecuniary interests in one of the mining companies and thus a conflict of interest.

While science and protests were on the margins of the debate, the role of mainstream media and individual sympathetic journalists was pivotal in bringing scientific knowledge and awareness that elite opinions were contested to the centre of public debate. John Büsst, Judith Wright, Barry Clouston and key journalists were able to develop a sophisticated media strategy. The campaign also used media to garner international support for the boycott of Ampol, which provided financial backing to a Japanese company that was about to commence the first drilling at Repulse Bay. The Gold Coast branch of the 'Save the Reef Committee' funded a full-page advertisement in the national newspaper, The Australian. This boycott would eventually garner support from Australian trade 
unions at the peak of controversy (Bowen and Bowen, 2002:262; Wright, 1977: 80-81). In 1968, a petition of 13,000 signatures was presented to Federal Parliament by the 'Save The Reef' campaign collected at various public gatherings including fairs and airports.

The campaign was also aided by the existing social relations of the main protagonists, not the least of which was John Büsst's old university friend, Australian Prime Minister Harold Holt. This gave the campaign direct access to the Australian Parliament, and to a host of powerful networks in Australia and internationally. The impact of this should not be understated, even if it remains somewhat invisible to contemporary research. We can conclude that policy development happened alongside, if not because of, the efforts of the 'Save the Reef' campaigners. Nascent here was policy that would administer the Reef for conservation, including the establishment of the Great Barrier Reef Marine Park Act and the Reef's listing as World Heritage, thus subjecting the Reef and Australian governments to an additional layer of surveillance and administration via the international policy program of the World Heritage Committee.

Throughout accounts of the campaign that emerged at the time, largely produced by 'insiders', the role of media and communications is acknowledged as important to the campaign's success but is of secondary interest to the machinations of the protest movement and strategies, relationships, conflict, power struggles and policy outcomes. Media are presented to some extent as 'outside' the protests with campaigners 'feeding' coverage and representation of their views to mainstream media and sympathetic journalists. Nevertheless, our analysis shows that 'Save the Reef' had a clear focus on coverage throughout, and this publicity was vital to pressure governments, unions, lawyers, scientists and the broader public to act.

\section{Fight for the Reef}

The context for the 'Fight For The Reef' campaign was both familiar and distinctive to that which had framed the 'Save the Reef' campaign. In the nearly 50 years between the campaign periods, global environmental consciousness, capital and communications became entrenched. Global and local environmental policies designed to administer and protect the Reef from destruction have also 
proliferated. In this context, 'Fight for the Reef's communication strategy is aimed at transcending national boundaries and bypassing traditional channels of power associated with media, government and industry. It produces its own images, video and news that are widely distributed via its website, youtube, and twitter, and places broadcast advertisements on Australian commercial television. While many of these techniques, including aiming for international reach and advertising in mainstream media, were evident in the earlier campaign, the scale of this communication has multiplied exponentially, to use Cottle's (2014) criteria, with professional international environmental groups and more localized ones able to access audiences amounting to hundreds of thousands. To quantify: in comparison to the 13,000 signatures delivered to Australian Parliament in 1968, the Fight For The Reef website (www.fightforthereef.org.au) had 234,518 members as of August 2015, its Facebook site had over 60,000 'likes' and an online petition of 81,000 signatures was delivered to the World Heritage Committee Meeting in Cambodia June 2013. Petitions containing hundreds of thousands of signatures have been delivered by Greenpeace to key World Heritage Committee meetings. Petitions, calling on international financiers to divest from projects that support the Carmichael Mine project and others in the Galilee Basin have also been collected internationally (Rainforest Action Network, 2015). These figures do not take into account the 'network of networks' characteristic of social media, but as some indication, WWF Australia, which is a partner organization to 'Fight for the Reef', has 155,000 members while WWF International had 1.6 million members as of August 2015.

Fight for the Reef's communication speed is also vastly different from the earlier campaign, with time and space collapsed to enable outcomes that carry the impact of suddenness. This is particularly the case with 'twitter storms' designed by 'Fight for the Reef' to coincide with World Heritage Committee meetings where Reef discussions have taken place. Different groups and memberships intersect in this new communications space, enabling social relations to connect and collate, thus empowering individuals and communities to share and support each other in the broadly united theme of mitigating Reef disaster. Fight for the Reef has formed alliances with other online protest 
movements including GetUp! Action for Australia, which boasts over 980,000 members and has been a tour de force in campaigning for social, economic and environmental justice (see Forde, 2011). GetUp!, in partnership with a local community organization Mackay Conversation Group and lawyers from the Environmental Defenders Office NSW, succeeded in having Adani's Carmichael mine approval overturned in the Australian Federal Court in 2015. In this case, the communication network collated funding for a legal case, whose impact was felt across the local/global continuum. The counter-response of the Australian federal government was to attempt to limit and remove legislation that empowers environmental NGOs to litigate against development projects where environments and biodiversity are threatened.

Local community knowledge and action intersect with international environmental and other NGOs, lawyers and scientists with speed and impact. In this communications and media landscape, 'Fight for the Reef' is less reliant on traditional media for the visibility of its environmental protest and conflict, able to write its own news and share across networks. While recognition in mainstream media is still an ambition in order to influence political decision makers and the implementation of policy, it is not critical to mobilizing public support and participation. Public mobilisation is a process that in itself maintains the capacity to pressure those who make decisions.

'Fight for the Reef' has orchestrated strategic interventions and interruptions to the taken-for-granted authority of governments and the resources industry in particular via their networks. Mainstream politics and media are very much a part of this $21^{\text {st }}$ century communication milleu, working alongside these new media involving 'simultaneously politics of representation and a politics of connectivity - both necessarily involved in scaling up and scaling down local global concerns' (Lester and Cottle, 2015: 108). This is evidenced by repeated high-profile and internationally distributed interventions in the Reef campaign by the Guardian news group; the involvement of Unilever's Ben and Jerry's icecream corporation via its 'Scoop Icecream, not the Reef' campaign; and Barak Obama's plea to the Australian Government to ensure his daughters and their descendants would still be able to visit the Reef (Lester, 2015). 
The impact of celebrity is also distinctive, symptomatic of a global communications industry where film stars, models and other entertainment personalities are newsworthy and powerful as a direct consequence of their participation in the entertainment industry (Lester, 2006; Goodman and Boykoff, 2009). In the case of Fight for the Reef, the impact of celebrity has been significant, especially in terms of increasing visibility. For example, when actor Leonardo Di Caprio attended an Oceans Conference in Washington DC, his comments on the Reef were reported widely via news services, tweeted and shared on Facebook, including in The Australian newspaper:

"Since my very first dive in the Great Barrier Reef in Australia 20-yearsago to the dive I got to do in the very same location just two years ago, I've witnessed environmental devastation first-hand," said DiCaprio, who pledged his own foundation would pump another $\$ 7$ million over the next two years into projects to help the oceans.

"What once had looked like an endless underwater utopia is now riddled with bleached coral reefs and massive dead zones.

"Unfortunately today, there's no proper law enforcement capacity and little accountability for violating the law. It's the Wild West on the high seas," warned the star of the box-office hit movie Titanic.' (The Australian, 2014)

The response from the campaign was to capitalize on Di Caprio's celebrity, naming him as a 'Reef Champion' on its 'Celebrity Wall'. Governments and the Reef tourism industry were subsequently incumbent to respond and have continued to defend the health of the Reef. The involvement of celebrity can create a 'powerful environmentalism', although conservation messages do not always result in positive outcomes, especially when local people and places are marginalized or ignored by global perspectives (Brockington, 2008). As well, at the very moment celebrity draws attention, it also reifies the status quo of neoliberalism and its partner, industrial capitalism, an unrelenting threat to the Reef and other environments. The same powers that would threaten the reef with industrial development have also bestowed DiCaprio and other celebrities with 
their power in the public domain - a contradiction of celebrity environmentalism and capitalism.

New media are equally available to governments and industry that may have a counter strategy to negate the impact of dissent emerging from environmental protest. Moreover, while this media ecology deems visibility likely, the availability of media and its democratic function of giving a voice to citizens can result in a cacophony of voices. In the public sphere, this noise risks a redundancy of voices and issues, of protest or issue fatigue as disasters, dangers and threats compete for popularity or recognition. With these critical caveats, Fight for the Reef is able to produce its own TV commercials, broadcast on corporate Australian TV and circulate its own maps to traditional media outlets but also via its network - and the network of networks. In ways which are both familiar and distinctive, this new media ecology maintains the democratic function of media, enabling citizen participation and voice in policy deliberations and decision making, while also revealing still emergent limitations to sustained influence and political power.

\section{Conclusion}

As Simon Cottle (2008: 855) indicates, a wealth of opportunities to distribute dissent, often challenging the existing orthodoxy, are created from the margins:

Transnational communication and delivery systems now facilitate the internationalization and globalization of some protests. ... today's complex media ecology, comprising different and overlapping media formations, horizontal and vertical communication flows and new interactional capabilities, offer unprecedented opportunities for the wider dissemination of political protest and dissent - from the local to the global... (Cottle, 2008: 855)

Our comparison of the protest campaigns, 'Save the Reef' and 'Fight for the Reef', has revealed salient and distinctive changes to media and communications practices and flows across the 50 year-period which the campaigns bookmark. Seemingly constant is the capacity of environmental 
protest, regardless of the era, to use media to pressure formal structures of environmental policy and legislation to impact perceived threats to the Reef posed by development applications. The most significant distinction is recognition by political actors that the expanded communication opportunities are more than mere vehicles - carriers - for environmental protest. In the earlier 'Save the Reef' era, campaigners represent themselves as passive, beholden to whims of established networks of power. 'Fight for the Reef', however, represents itself as able to force dominant power structures to engage in interactions outside their control. In this way, new networks of power resemble historical incarnations but with the qualification that societal power relations can be increasingly shaped and decided in the communications field (Castells, $2007,2009)$. Here, the media's role in the Reef protests is clearly acknowledged as creative, seen to empower a participatory politics that wrestles public debate from existing sites of cultural and economic power such as mainstream commercial media, industry and governments.

We need to ask, however, how this shift has actually affected outcomes for the Reef. The dominant motifs of both campaigns are the threats of industrial development and their potential to have disastrous consequences for the Reef. While in 2015 the Reef itself is not to be mined, the threats posed by the development of the resources industry remain, amplified within the context of climate crisis, a clear connection to fossil fuels and the impact of warming waters on Reef ecosystems. It might seem reasonable to have expected more for the Reef in 2015, given the perceived empowerment of Reef activists via global communications and supported by interconnected layers of environmental policy - environmental policy that in this case is determined and administered across local, national and international levels.

Principal among recent concerns from the 2012 UNESCO/World Heritage Centre-IUCN monitoring mission report (2012: 4-5) were proposals to develop the Galilee Coal Basin and LNG gas projects, alongside the substantial development and expansion of infrastructure to support these new developments including port construction, seabed dredging and dumping to enable increased shipping traffic and rail development. To be clear, these proposals are gargantuan in both size and impact, with the extraction of coal in particular undermining global efforts to 
thwart potential climate change catastrophe. It has been suggested that even the development of one mine in the Galilee Basin, the Carmichael mine, 'is easily capable of destroying the reef (pushing the added carbon dioxide well beyond the 500-800-gigatonne budget), along with many other ecosystems too' (HoeghGuldberg, 2015). To date, a community of dissent and a plethora of policy have not swayed the major Australian political parties and governments to discontinue to support these development proposals. The success of the earlier 'Save the Reef' campaign is evident, with drilling halted and the development of a raft of policies and laws to protect the Reef. 'Fight the Reef' has had significant wins in impeding current development proposals, but despite its unparalleled access to communications tools and networks, has been unable to sway political decision-makers to abandon the development proposals.

Opportunities continue for these Great Barrier Reef protests to manufacture strategic interventions and interruptions or breakthrough moments when the powerful institutional actors of governments and industry both national and international are held to account. Media and communications should present unprecedented power for civil society actors to impact upon formal processes of definitions and decision making. Here, media and ecological democracy are enacted at the confluence of participation in media and in environmental decision-making (Foxwell-Norton, 2015). These are critical and consequential processes that strike to the heart of relations between media, politics and environment in the $21^{\text {st }}$ century. Yet, our analysis of the two campaigns crossing five decades, within the context of the current threatened state of the Reef, suggests that there is still a concerning power disjuncture between emerging media and communications practices and logics and the enactment of sustained and meaningful policy.

\section{References}

Adani. (2014). Carmichael Coal Mine and Rail Project. Available at: http://www.adanimining.com/Australia-Carmichael-coal (accessed 14 August).

Australian Govenrment (n.d.) The World Heritage Convention. Available at: 
http://www.environment.gov.au/heritage/about/world/world-heritageconvention (accessed August 30 2015).

Beck U (2009), World at Risk. Cambridge: Polity Press.

Bowen J and Bowen M(2002) The Great Barrier Reef: History, science, heritage.

Cambridge: Cambridge University Press.

Boykoff M T and Goodman M K (2009) Conspicuous redemption? Reflections on the promises and perils of the 'celebritization' of climate change. Geoforum 40(3): 395-406.

Brockington D (2008) Powerful Environmentalisms. Conservation, Celebrity and Capitalism. Media, Culture and Society 30: 551-568.

Carson R (1962) The Silent Spring. USA:Houghton Mifflin.

Castells M (2007) Communication, power and counter-power in the network society. International Journal of Communication 1(1): 238-66.

Castells M (2009) Communication power. Oxford/New York: Oxford University Press.

Clare P (1971) The Struggle for the Great Barrier Reef. Sydney:Collins.

Connell DW (1971) The Great Barrier Reef conservation issue-A case history. Biological Conservation 3(4): 249-254.

Cosgrove DE (1984) Social Formation and Symbolic Landscape. London: Croom Helm.

Cottle S (2006) Mediatised Conflict. Maidenhead: Open University Press.

Cottle S (2008) Reporting Demonstrations: The Changing Media Politics of

Dissent. Media, Culture and Society 28(2): 853-872.

Cottle S (2009) Global Crisis Reporting: Journalism in the Global Age. Maidenhead: Open University Press.

Cottle S (2014) Rethinking media and disasters in a global age: What's changed and why it matters. Media, War and Conflict 7(1): 3-22.

Cox R (2012) Environmental Communication and the Public Sphere - Third Edition. USA: Sage

Deloitte Access Economics (2013) Economic contribution of the Great Barrier

Reef. Townsville: Great Barrier Reef Marine Park Authority.

Drew P (1994) The Coast Dwellers: Australians living on the Edge. Victoria:

Penguin. 
Evans R (2007) A History of Queensland. Australia: Cambridge University Press.

Forde S (2011) Challenging the News: The Journalism of Alternative and Independent Media. London: Palgrave Macmillan.

Foxwell-Norton K (2015) Community and Alternative Media: Prospects for 21st

Century Environmental Issues. In: Atton C (ed) The Routledge Companion to Community and Alternative Media. UK:Routledge, 389-400

Hansen A (2010) Environment, media and communication. New York: Routledge. Hoegh-Guldberg O (2015) Coal and climate change: A death sentence for the Great Barrier Reef. The Conversation, 20 May.

Hutchins B and Lester L (2015) 'Theorizing the Enactment of Mediatized Environmental Conflict', International Communication Gazette (published online).

Hutton D and Connors L (1999) A History of the Australian Environment Movement. Cambridge University Press: Melbourne.

Lester L (2010) Media and Environment: Conflict, Politics and the News. Cambridge: Polity.

Lester L (2014) 'Transnational Publics and Environmental Conflict in the Asian Century', Media International Australia, 150: 67-78.

Lester L (2015) 'Containment and Reach: The changing ecology of environmental communication: News and new media roles', Chapter 19. In: A. Hansen and R. Cox (eds) Routledge Handbook of Environmental Communication, Abingdon: Routledge.

Lester L and Cottle S (2009) 'Visualising Climate Change: TV News and Ecological Citizenship', International Journal of Communication, 3, pp. 920-936.

Lester L and Cottle S (2015) Transnational protest, publics and media participation (in an information age). In: Hansen A and Cox R (eds), The Routledge Handbook of Environment and Communication, Routledge: Oxon, 100-110.

Lester L and Hutchins B (2009) ‘Power Games: Environmental Protest, News Media and the Internet,' Media, Culture \& Society, 31(4), pp. 579-595.

Lester L and Hutchins B (eds) (2013) Environmental Conflict and the Media. New York: Peter Lang. 
McCalman I (2013) The Reef: A Passionate History from Cook to Climate Change. Australia:Viking/Penguin Books.

NASA (2014), Apollo 8: Christmas at the Moon, http://www.nasa.gov/topics/history/features/apollo_8.html (accessed 26 October, 2015)

Queensland Heritage Register (n.d) Ninney Rise and John Büust Memorial. Available at: https://heritage-

register.ehp.qld.gov.au/placeDetail.html?siteId=19622 (accessed July 15 2015).

Rainforest Action Network (2015), Over 670,000 Call On Ex-Im Bank To Reject Controversial Australian Coal Project. Available at: http://www.ran.org/tags/great_barrier_reef (accessed October 27 2015).

The Australian (2014), 'Leonardo Dicaprio tells of Great Barrier Reef 'devastation'. Available at: http://www.theaustralian.com.au/nationalaffairs/leonardo-dicaprio-tells-of-great-barrier-reef-devastation/storyfn59niix-1226958336644 ( accessed August 30 2015)

UNESCO World Heritage Centre - IUCN (2012) MISSION REPORT Reactive Monitoring Mission to Great Barrier Reef(Australia), 6th -14th March 2012 Wright J (1977 [2014]). The Coral Battleground. North Melbourne: Spinifex Press. 
${ }^{i}$ This paper is one of a series of articles emerging from a larger research project that is investigating the communication of the Great Barrier Reef, exploring critical moments in ongoing protection and conservation efforts. These moments have complex 'relations of definition' (Beck, 2009) articulating historical and contemporary contexts framed by Reef science, policy, media, law, protest and communities. This work is adopting a multi-methodological approach informed by an extensive literature review of GBR communication across disciplinary publications including history, science and law, content collection and analysis of media reporting of critical Reef moments, analysis of insider accounts of GBR protest and policy, fieldwork with key activists in the contemporary era, public symposium discussion and presentations (see Communication4Conservation ) alongside ongoing participant observation in the contemporary Fight for the Reef protest via traditional and social media. 